\title{
THEORETICAL FOUNDATIONS OF FINANCIAL CONTROLLING JOINT ACTIVITIES AS A CONCEPT OF BUSINESS ADMINISTRATION
}

\author{
Alla Dmytrenko, PhD in Economics, Associate Professor \\ Valeria Kolisnyk \\ National University «Yuri Kondratyuk Poltava Polytechnic»
}

\author{
(C) Dmytrenko R., 2019 \\ (C) Kolisnyk A., 2019 \\ Стаття отримана редакиією 02.12.2019 p. \\ The article was received by editorial board on 02.12.2019
}

Problem solving. The development of a market economy in Ukraine requires the development and application of new approaches in managing enterprises and the conditions of their functioning in the market. In order to survive for businesses, it is necessary to properly define their strategy and tactics of market behavior and to systematically manage the activity of the enterprise in order to improve the efficiency of the activity. The application of the system of financial controlling is a new trend in the enterprise management system as a functionally separated area of financial work related to the implementation of the financial and economic function.

Analysis of recent scientific researches. Considerable attention was paid to the study of the theory and practice of financial controlling in the works by such domestic and foreign scientists, namely: I.A. Blank [1], M.P. Butko [2], Sh. Wang [3], Y. Weber [4], O. Klockar [7], H.O. Partyn [9], N.D. Sobkova [13], I.B. Stefanyk [11], D.H. Savchuk, O.O. Tereshchenko [14, 15], R. Hilton [5], P. Horvath [6], K. Surfing [12] and others. However, the role of financial control as an integral part of a joint venture's management system, which ensures its effective functioning, does not fully reveal the need for further investigation.

The purpose of the article. The purpose of the article is to study the main characteristics, to develop methodological bases and practical recommendations for the implementation of financial control at a joint venture as an important component of the management system.

Presenting the basic material. The introduction of controlling at enterprises and organizations showed that types of controlling can be classified not only on the principle of coverage (strategic and operational), but also in the areas of activity - financial controlling, controlling of marketing, logistics, investments, innovative processes, controlling of personnel, etc. One of its central areas in the overall controlling system organized at the enterprise is financial control.

Financial controlling is an effective coordinating system for ensuring the relationship between the formation of information base, financial analysis, financial planning and internal financial control, which ensures concentration of control actions on the most priority areas of financial activity of the enterprise, timely detection of deviations of its actual results from the envisaged and adoption of operational management solutions that ensure its normalization.

At the same time, financial controlling can be interpreted as a system of information support for the coordination of all management subsystems, which involves the use of methods and procedures for budgeting, strategic planning, management accounting, financial diagnostics, investor relations, risk management and internal control, which are collectively focused on improving financial efficiency, economic solutions and increasing the value of the company [15].

Financial control is at least also oriented to the current activity of the enterprise, as it provides for the improvement of the efficiency of making prompt management decisions.

In this case, financial controlling is becoming increasingly important for the current management of the enterprise, which is caused by the rapid changes in the conditions of activity of both the enterprise and their clients. In such circumstances, it is advisable to speak about the introduction of financial control, which will allow you to make typical management decisions as quickly as possible. This involves the availability of appropriate software and the development of specific scoring control techniques.

Noteworthy is the point of view of domestic researchers H. Partyn and Ya. Maievska, who define financial controlling as a management philosophy: arguing that it is the art of management (management 
system), aimed at determining the future financial well-being of the enterprise and ways to achieve it $[9, \mathrm{p}$. 199].

Examining the perspectives of different scholars, it is established that there are different approaches to interpreting the essence of financial control as a social category. They are similar to each other and differ only in individual components. Thus, the overwhelming number of scientists under this category understands the system of financial management of the development of business entities in the direction of forecasting and planning the mechanisms and instruments for achieving sustainable financial status $[5$, p. $117 ; 7$, p. 11; 14, p. 12].

Before interpreting the essence of financial controlling, it is advisable to distinguish its basic stages of formation and development and their corresponding concepts during each period of time.

The main stages of the formation and development of financial control include:

1) the era of the "seller's market", which began the development of functional management and management accounting;

2) the era of "buyer's market" contributed to the emergence of strategic, financial and process management, as well as engineering the organizational structure of the enterprise;

3) the globalization of markets for sales, production, and resource support has influenced the emergence of this type of management, such as "management outsourcing";

4) the globalization of financial markets has highlighted "quality management" (not "quality management") and "shareholder value management". [11, p. 27-31].

In today's socio-economic conditions of society there are three concepts of improving the organization and implementation of financial control [3]. One of the first is a concept whereby financial control is focused on the control function. In the writings of the American economist R. Hilton substantiates the concept of controlling, which focuses mainly on control functions [5, p. 149].

A similar approach in the treatment of controlling was applied by I. Blank and proved that financial controlling is a controlling system, which ensures concentration of control procedures in the most priority areas of financial activity of the enterprise [1, p. 119].

Control function is also a priority in Chinese practice of controlling organization.

The second modern concept of financial controlling is that it performs an information function. Conventionally, this concept covers the accounting and analytical functions mentioned above.

According to T. Reichmann, the controlling system should be focused primarily on the information support of the planning and control process. The content of the concept is that controlling is an element of the information system of the enterprise and is oriented to the collection, processing and verification of information for making management decisions [10, p. 13].

According to the German scientist K. Surfing, controlling is a system of information support of management decisions on the basis of planning, control, analysis and development of alternative measures for management of production and economic processes in the enterprise. According to this concept, the introduction of a controlling service at enterprises and organizations is due primarily to the need to reduce information asymmetry between management and objects of financial management [12, p. 120].

It should be noted that in order to overcome information mismatch between individual entities of financial and economic activity of any enterprise, it is necessary to implement the concept of coordination as a leading function of financial controlling. The concept covers coordination and navigation and integration tasks. J. Weber saw the essence of financial control in "coordinating the management system". However, the scientist believed that it is impossible to put a sign of equality between financial controlling as a function of coordination and management system [4, p. 21].

The idea of controlling based on the priority of the coordination function is based on the interpretation of controlling as an independent control subsystem.

According to the scientist P. Horvath, this subsystem is aimed at system-forming and systemintegration coordination: within the subsystem of management and between its individual subsystems, taking into account the peculiarities of the management system; to support management to meet specific coordination objectives, taking into account the objectives set. That is, it implies, first of all, coordination of planning and control, as well as information support [6, p. 22].

The analysis of numerous literary sources showed that most often scientists allocate such functions of financial controlling at the enterprise [3, p. 90]:

coordination;

financial strategy;

planning and budgeting; 


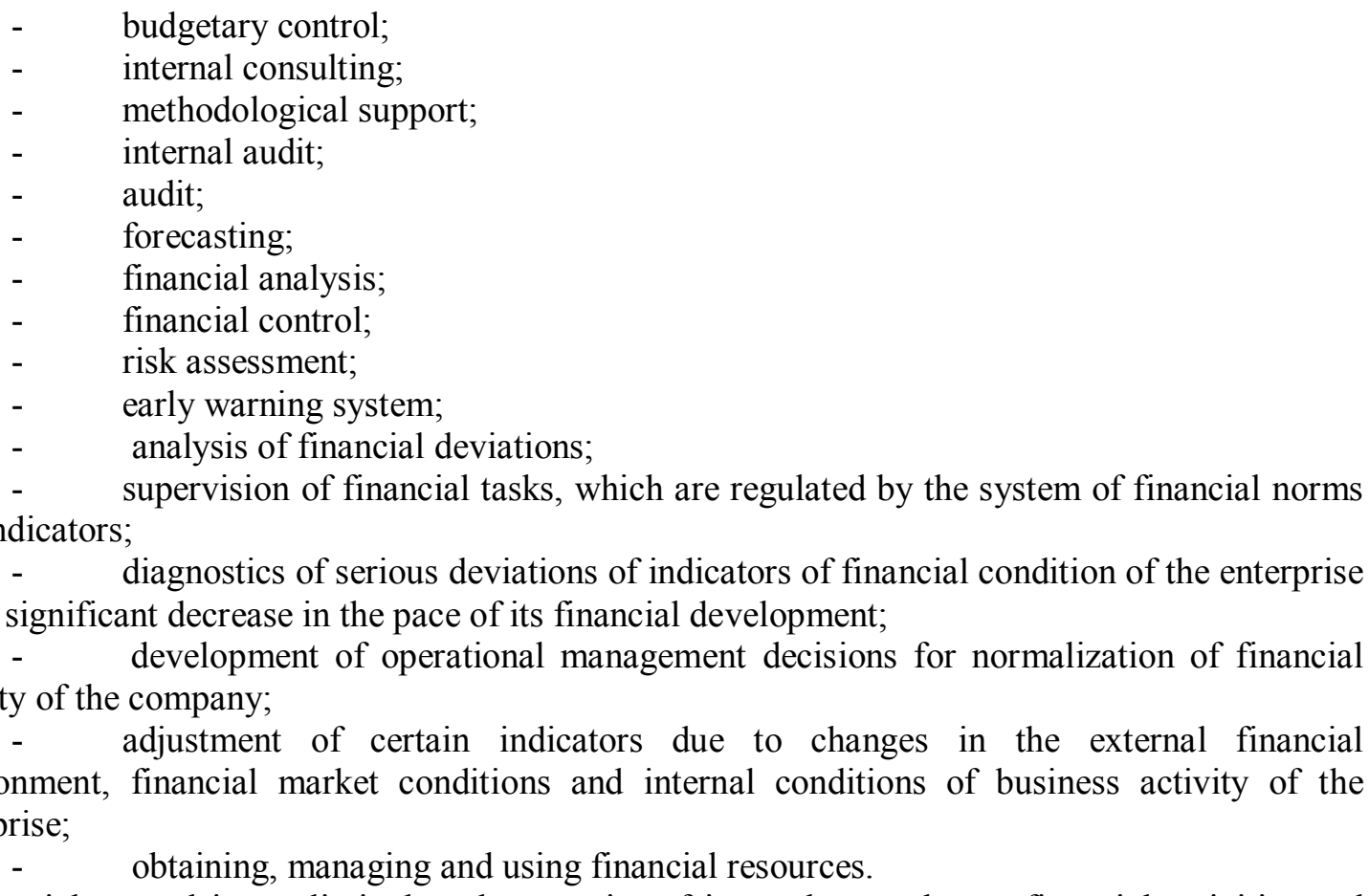

Thus, financial control is not limited to the exercise of internal control over financial activities and financial transactions, but is an effective coordinating system to ensure the relationship between the formation of the information base, financial analysis, financial planning and internal financial control in an industrial enterprise.

Therefore, financial controlling should be defined as a subsystem based on financial performance. Accordingly, financial controlling is a set of functions to ensure a stable financial position of an enterprise: liquidity and solvency.

Financial controlling is a multifunctional subsystem of sound management decision-making based on the methods of financial analysis and financial planning, financial control, timeliness, simplicity and flexibility of financial control system construction.

As practice shows, the introduction of controlling at joint ventures is fraught with numerous problems. The main groups of factors that hinder the successful organization of controlling at a joint venture include: historical, driven by views on doing business, opacity, not always sufficient economic knowledge of managers; psychological, related to the skeptical views of management on the introduction of financial control, the results of which are not noticeable immediately, but rather expensive and long-lasting; organizational, due to lack of experience in formulating the desired results from the implementation of financial control, the difficulty of attracting skilled workers to this process; methodical, which arise as a result of ignoring the necessary business restructuring, unsuccessful allocation of responsibility centers at the enterprise, choosing inadequate principles of transfer pricing, planting destructive motivational models, ignoring the need to create a package of corporate control standards.

Financial controlling has a comprehensive impact on the activities of the joint venture and ensures its functioning on the basis of constant coordination between different phases of the cycle (accounting, analysis, planning, monitoring and control).

Thus, the main task of financial control is not only to control, but also to ensure the relationship between the components of the overall enterprise management system.

Conclusions and suggestions. Financial control has a comprehensive impact on the activities of the joint venture and ensures its development on the basis of constant coordination between different phases of the cycle (accounting, analysis, planning, monitoring and control). The main task of financial control is not only control but also ensuring the interconnection between the components of the overall enterprise management system.

In today's economic environment, it is quite difficult to quantify changes in the sustainable development management system of an enterprise.

The foregoing experts note the qualitative manifestation of the positive results of the implementation of financial control, which is as follows:

increasing the degree of adaptation of the company to the changing market conditions; 
- $\quad$ increasing the speed of response to changes in the internal and external environments in order to achieve the set goals; improving the functioning of the financial planning system in order to increase the efficiency of redistribution of financial resources of the enterprise;

decisions;

timely receipt of accurate information necessary for making financial management

improving the level of adequacy of financial management decisions.

\section{REFERENCES:} $-592 \mathrm{p}$.

1. Blank I.A. Fundamentals of Financial Management / I.A. Blank. - K.: Nika-Center, 1999. - Vol. 1.

2. Butko M.P. Organization of the controlling system at the enterprises of Ukraine / M.P. Butko // Scientific Bulletin of the Kherson State University. - 2014. - Edition 6. Part 2. - P. 116-118.

3. Wang Sh. Manifestations of Controlling in the People's Republic of China / Sh. Wang // Controlling in Business: Theory and Practice. Forming a market economy: Coll. of sciences. works. - K.: KNEU, 2008. - P. 20-25.

4. Weber J. Kalkulation von Logistikkosten / J. Weber // Logistic Controlling: Konzepte - Instrumente - Wirtschaftlichkeit / [Wolfgang Mannel (Hrsg.)]. - Wiesbaden, 1993. - P. 109-123. doi: 10.1007/9783 322825261 7.

5. Hilton R.W. Managerial Accounting / R.W. Hilton. - [5. A.]. - New York, 2002. - 526 p.

6. Horvath P. Controlling / Peter Horvath. - [12 Auflage]. - München, 2011. - 848 p. doi: 10.15358/ 9783800644551.

7. Klokar O. The socio-economic essence of financial controlling and its effective formation and development / Oleh Klokar // EAST. - 2016. - No. 5 (145). - P. 11-15.

8. Papp V.V., Boshota N.V. Financial Controlling as a Basis for Effective Enterprise Finance Management. [Electronic resource] / V.V. Pope, N.V. Boshota. - Access mode: http: //www.nbuv.gov.ua/portal/ soc_gum / Staptp / 2014_53 / files / ST53_38.pdf - Screen name 20.05.2017. "Young Scientist". - No. 11 (14). - November, 2014. - P. 90-92.

9. Partyn H.O. Types and place of financial controlling at the enterprise / H.O. Partyn, Ya.V. Maievska // Scientific Bulletin of NLTU Ukraine. - 2009. - No. 19.6. - P. 199-202.

10. Reichmann T. Controlling mit Kennzahlen. Die systemgestutzte Controlling Konzeption mit Analyze und Reportinginstrumenten / Thomas Reichmann. - [8 Auflage]. - Munich, 2011. doi: 10.15358 / 9783800643752.

11. Safarov O.I. Controlling practice: what hinders the success of its implementation? / O.I. Safarov // Current problems of economy. - 2008. - № 4. - P. 27-31.

S.

12. Serfling K. Controlling / K. Serfling. - 2 Aufl. - Stuttgart, Berlin, Koln: Kohlhammer, 1992. - 360

13. Sobkova N.D. Conceptual features of controlling in the financial system of Ukraine / ND. Sobkova // Formation of market relations. - 2009. - № 2. - P. 17-22.

14. Tereshchenko O.O. The concept of financial control in Ukraine / O.O. Tereschenko // Finance of Ukraine. - 2008. - № 1. - P. 12-14.

15. Tereshchenko O.O., Stashchuk D.M., Savchuk D.G. The current state and prospects of development of financial controlling (to the results of Ukrainian-Russian "round table") // Finance of Ukraine. - 2011. - № 2. - P. 117-126.

UDC 658.012.32

Дмитренко Алла, кандидат економічних наук, доцент. Колісник Валерія. Національний університет «Полтавська політехніка імені Юрія Кондратюка». Теоретичні засади фінансового контролінгу спільної діяльності як концепції управління у сфері бізнесу. Розвиток ринкової економіки в Україні вимагає розроблення та використання нових підходів в управлінні підприємствами й умов їх функціонування на ринку. Застосування системи фінансового контролінгу $\epsilon$ новим напрямом у системі управління підприємством як функціонально відокремленого напряму фінансової роботи, пов'язаного 3 реалізацією фінансово-економічної функції. Дослідженно роль фінансового контролінгу як складової системи управління стійким розвитком спільного підприємства. Схарактеризовано основні етапи, концепції, функції, принципи формування та розвитку фінансового контролінгу. Обгрунтовано необхідність організації й запропоновано основні етапи впровадження фінансового контролінгу в управління розвитком спільного підприємства. 
Якісний прояв позитивних результатів упровадження фінансового контролінгу полягає у :

- підвищенні ступеня адаптації підприємства до швидкозмінних ринкових умов;

- зростанні швидкості реагування на зміни у внутрішньому та зовнішньому середовищі 3 метою досягнення встановлених цілей поіпшенні функціонування системи планування фінансової діяльності з метою підвищення ефективності перерозподілу фінансових ресурсів підприємства;

- своєчасності отримання точної інформації, необхідної для прийняття фінансових управлінських рішень;

- підвищенні рівня адекватності фінансових управлінських рішень.

Ключові слова: фінансовий контролінг,. концепції фінансового контролінгу, етапи фінансового контролінгу, функції фінансового контролінгу, спільне підприємство.

\section{UDC 658.012 .32}

Dmytrenko Alla,, PhD in Economics, Associate Professor. Kolisnyk Valeria. National University «Yuri Kondratyuk Poltava Polytechnic». Theoretical foundations of financial controlling joint activities as a concept of business administration. The role of financial controlling as an integral part of the joint venture sustainable development management system is investigated in the article. The basic stages, concepts, functions, principles of formation and development of financial controlling are characterized. The necessity of organization is substantiated and the basic stages of introduction of financial control in management of development of joint venture are proposed.

Keywords: financial controlling, concepts of financial controlling, stages of financial controlling, functions of financial controlling, joint venture.

\section{UDC 658.012.32}

Дмитренко Алла, кандидат экономических наук, доцент. Колесник Валерия. Национальный университет «Полтавская политехника имени Юрия Кондратюка». Теоретические основы финансового контроллинга совместной деятельности как концепции управления в сфере бизнеса. Развитие рыночной экономики в Украине требует разработки и использования новых подходов в управлении предприятиями и условий их функционирования на рынке. Применение системы контроллинга является новым направлением в системе управления предприятем как функционально обособленного направления финансовой работы, связанного с реализацией финансово-экономической функции. Исследована роль финансового контроллинга как составляющей системы управления устойчивым развитием совместного предприятия. Охарактеризованы основные этапы, концепции, функции, принципы формирования и развития контроллинга. Обоснована необходимость организации, и предложены основные этапы внедрения контроллинга в управление развитием совместного предприятия. Качественное проявление положительных результатов внедрения контроллинга заключается в:

- повышении степени адаптации предприятия к быстроменяющимся рыночным условиям;

- росте скорости реагирования на изменения во внутренней и внешней среде с целью достижения установленных целей;

- улучшении функционирования системы планирования финансовой деятельности с целью повышения эффективности перераспределения финансовых ресурсов предприятия;

- своевременности получения точной информации, необходимой для принятия финансовых управленческих решений;

- повышении уровня адекватности финансовых управленческих решений.

Ключевые слова: финансовый контроллинг, концепции финансового контроллинга, этапы финансового контроллинга, функции контроллинга, совместное предприятие. 